\title{
Salinibacter ruber gen. nov., sp. nov., a novel, extremely halophilic member of the Bacteria from saltern crystallizer ponds
}

\footnotetext{
1 División de Microbiología, Departamento de Fisiología, Genética y Microbiología, Universidad de Alicante, Apto 99, 03080 Alicante, Spain

2 Division of Microbial and Molecular Ecology, The Institute of Life Sciences and The Moshe Shilo Minerva Center for Marine Biogeochemistry, The Hebrew University of Jerusalem, 91904 Jerusalem, Israel

${ }^{3}$ División de Microbiología, Universidad Miguel Hernández, Campus de San Juan, 03550 San Juan, Alicante, Spain

${ }^{4}$ Max-Planck-Institut für Marine Mikrobiologie, D-28359 Bremen, Germany

${ }^{5}$ Laboratori de Microbiologia, Departament de Biologia, Facultat de Ciències, Universitat de les Illes Balears, 07071 Palma de Mallorca, Spain
}

\author{
Josefa Antón, ${ }^{1}$ Aharon Oren, ${ }^{2}$ Susana Benlloch, ${ }^{3}$ Francisco Rodríguez- \\ Valera, ${ }^{3}$ Rudolf Amann ${ }^{4}$ and Ramón Rosselló-Mora ${ }^{5}$
}

\author{
Author for correspondence: Josefa Antón. Tel: + 34 965903870. Fax : + 34965909569 \\ e-mail: anton@ua.es
}

\begin{abstract}
Five brightly red-pigmented, motile, rod-shaped, extremely halophilic bacteria were isolated from saltern crystallizer ponds in Alicante (two strains) and Mallorca (three strains), Spain. They grew optimally at salt concentrations between 20 and $30 \%$ and did not grow below $15 \%$ salts. Thus, these isolates are among the most halophilic organisms known within the domain Bacteria. The temperature optimum was $37-47^{\circ} \mathrm{C}$. A single, yet to be identified pigment was present, with an absorption maximum at $482 \mathrm{~nm}$ and a shoulder at 506-510 nm. The G+C content of the DNA was 66.3-67.7 mol\% and, together, they formed a homogeneous genomic group with DNA-DNA similarities above $70 \%$. The 165 rRNA gene sequences were almost identical to sequences recovered earlier from the saltern biomass by amplification of bacterial smallsubunit rRNA genes from DNA extracted from the environment. This phylotype, earlier described as 'Candidatus Salinibacter', was shown by fluorescence in situ hybridization to contribute between 5 and $25 \%$ of the prokaryote community of the saltern crystallizers. We have therefore succeeded in isolating a bacterium from the natural environment that, although being a major component of the community, was previously known by its phylotype only. Isolation of the organism now allows formal description of a novel genus and species, for which we propose the name Salinibacter ruber gen. nov., sp. nov. The type strain is strain M31 $^{\top}$ ( $=$ DSM $13855^{\top}=$ CECT $\left.5946^{\top}\right)$.
\end{abstract}

Keywords: Salinibacter, extreme halophiles, salterns, Rhodothermus

\section{INTRODUCTION}

Until recently, it was assumed that representatives of the domain Bacteria do not play a major role in the microbial community of hypersaline brines at or approaching $\mathrm{NaCl}$ saturation. Few heterotrophic bacteria were known to grow at such high salt concentrations and those were outcompeted by halophilic members of the Archaea under the conditions prevailing in such environments (Oren, 1994; RodríguezValera et al., 1980).

\footnotetext{
Abbreviations: $\mathrm{FISH}$, fluorescence in situ hybridization; SW, sea water. The GenBank/EMBL/DDBJ accession numbers for the $16 \mathrm{~S}$ rDNA sequences of strains M1, M31', M8, Pola-18 and Pola-13 are respectively AF323499-AF323502.
}

Indications that saltern crystallizer ponds may harbour significant communities of bacteria that live together with the red archaea were obtained recently using molecular biological approaches. Amplification of small-subunit rRNA sequences from DNA collected from Spanish crystallizer ponds yielded a novel phylotype, clustering near the Cytophaga-FlavobacteriumBacteroides group (Antón et al., 2000). The rRNA sequences most closely related to this phylotype belong to the genus Rhodothermus, which consists of slightly halophilic, thermophilic bacteria isolated from marine hot springs (Alfredsson et al., 1988; Sako et al., 1996). Using fluorescent probes designed for the detection of the novel phylotype, it was shown that it belongs to rod-shaped bacteria that are abundant in the Spanish saltern ponds, contributing between 5 and $25 \%$ of the total prokaryotic community. Enrichment of the en- 
vironmental samples with low concentrations of yeast extract resulted in an increase in cell numbers harbouring this phylotype. In these experiments, the salt optimum for growth was found to be between 20 and $25 \%$, i.e. in the same range as the most halophilic archaea of the Halobacteriaceae. The new type of extremely halophilic bacteria was described on the basis of these environmental studies as 'Candidatus Salinibacter' (Antón et al., 2000).

We have now isolated a number of extremely halophilic bacteria from saltern ponds in Mallorca and Santa Pola, Alicante, Spain, with 16S rRNA sequences almost identical to those of the 'Candidatus Salinibacter' phylotype. They are all brightly red-coloured, rod-shaped bacteria. They are among the most halophilic bacteria known, requiring at least $15 \%$ salts for growth. The isolation in culture of organisms that correspond to the phylotype 'Candidatus Salinibacter', their characterization and deposition in culture collections allows the description of Salinibacter gen. nov. A formal description of Salinibacter gen. nov. with the type species Salinibacter ruber sp. nov. is presented below.

\section{METHODS}

Source of strains. Salinibacter isolates were obtained from brine samples collected from crystallizer ponds of salterns located at Santa Pola (Alicante) and Mallorca. Information on the isolates and their source of isolation is summarized in Table 1 .

Media, isolation and culture conditions. Samples or dilutions thereof were plated on different hypersaline agar media. Strain Pola-18 was isolated from an agar plate of R2A medium (Difco), supplemented with $25 \%$ crude solar salt, on which $0 \cdot 1 \mathrm{ml}$ of a $10^{-2}$ dilution of the sample in $80 \%$ autoclaved brine was spread, followed by incubation at $37^{\circ} \mathrm{C}$. Isolate Pola-13 was derived from a red colony that appeared on a plate of R2A agar supplemented with $20 \%$ $\mathrm{NaCl}, 2 \% \mathrm{MgSO}_{4} \cdot 7 \mathrm{H}_{2} \mathrm{O}$ and $0 \cdot 2 \%$ bentonite and inoculated with $0 \cdot 1 \mathrm{ml}$ of a $10^{-5}$ dilution of the same brine. The Mallorca isolates all came from agar plates [salt solution $25 \%$ sea water (SW) containing $1^{-1}: 195 \mathrm{~g} \mathrm{NaCl}, 34.6 \mathrm{~g}$ $\mathrm{MgCl}_{2} \cdot 6 \mathrm{H}_{2} \mathrm{O}, 49 \cdot 5 \mathrm{~g} \mathrm{MgSO}_{4} \cdot 7 \mathrm{H}_{2} \mathrm{O}, 1 \cdot 25 \mathrm{~g} \mathrm{CaCl}_{2} \cdot 2 \mathrm{H}_{2} \mathrm{O}$, $\left.5 \mathrm{~g} \mathrm{KCl}, 0.25 \mathrm{~g} \mathrm{NaHCO}_{3}, 0.625 \mathrm{~g} \mathrm{NaBr}\right]$ with $0.1 \%$ yeast extract (referred to below as medium B) streaked directly with water from the crystallizer pond. After growth, cells from colonies were examined microscopically, rods were selected and inoculated again on the same medium. Strains Pola-18 and Pola-13 were recognized as members of the Bacteria based on polar lipid analysis, while the Mallorca strains were identified as Salinibacter by fluorescence in situ hybridization (FISH) using the specific FISH probe EHB412 (Antón et al., 2000).

The Salinibacter strains were routinely grown in liquid culture in medium of the following composition (referred to below as medium A) $\left(1^{-1}\right): 200 \mathrm{~g} \mathrm{NaCl}^{2} 20 \mathrm{~g} \mathrm{MgSO}_{4} .7 \mathrm{H}_{2} \mathrm{O}$, $1 \mathrm{~g} \mathrm{KCl}, 0.3 \mathrm{~g} \mathrm{KH}_{2} \mathrm{PO}_{4}, 0.5 \mathrm{~g}$ yeast extract, $0.5 \mathrm{~g}$ Bactopeptone, $0.5 \mathrm{~g}$ Casamino acids, $0.5 \mathrm{~g}$ glucose, $0.5 \mathrm{~g}$ starch and $0.3 \mathrm{~g}$ sodium pyruvate. The $\mathrm{pH}$ was adjusted to 7.2 with $\mathrm{NaOH}$ prior to autoclaving and readjusted after autoclaving. Another suitable medium was medium B (see above). For solid media, agar was added at $20 \mathrm{~g} \mathrm{l}^{-1}$.

Growth conditions. For each of the five strains, cultures were prepared in medium B with different salt concentrations (5, $10,15,20,25,30 \% \mathrm{SW}$ and $30 \% \mathrm{SW}$ plus $\mathrm{NaCl}$ up to saturation), $\mathrm{pH}$ values $(5 \cdot 5,6,7,8$ and 9$)$, yeast extract concentrations $(0 \cdot 1,0 \cdot 2,0.5$ and $1 \%)$ and incubation temperatures $\left(27,32,37,42,47,52\right.$ and $\left.57^{\circ} \mathrm{C}\right)$. The influence of $\mathrm{Mg}^{2+}$ concentration on the growth rate was checked using modified medium $\mathrm{B}\left(1^{-1}: 195 \mathrm{~g} \mathrm{NaCl}, 1 \cdot 25 \mathrm{~g} \mathrm{CaCl}_{2} .2 \mathrm{H}_{2} \mathrm{O}\right.$, $5 \mathrm{~g} \mathrm{KCl}, 0.25 \mathrm{~g} \mathrm{NaHCO}_{3}, 0.625 \mathrm{~g} \mathrm{NaBr}, 0.1 \%$ yeast extract) supplemented with increasing concentrations of $\mathrm{MgCl}_{2} .6 \mathrm{H}_{2} \mathrm{O}(0 \cdot 05,0 \cdot 1,0 \cdot 2,0 \cdot 4$ and $0.6 \mathrm{M})$. For $\mathrm{pH}-$ controlled experiments, different buffers [MES ( $\mathrm{pH} 5-6$ ), Tris (pH 7-9)] were added at a concentration of $20 \mathrm{mM}$. Cells were grown in $15 \mathrm{ml}$ volumes in $50 \mathrm{ml}$ tubes or in $50 \mathrm{ml}$ volumes in $250 \mathrm{ml}$ Erlenmeyer flasks with shaking (150-200 r.p.m.) at $37^{\circ} \mathrm{C}$, unless specified otherwise. Growth was monitored by measuring optical density at $600 \mathrm{~nm}$ throughout the growth curve until stationary phase was reached or for at least 14 days.

Microscopy. Cell morphology and motility were examined using a Zeiss standard microscope equipped with phasecontrast optics. For photography, drops of culture were mixed on a microscope slide with an equal volume of melted $2 \%(\mathrm{w} / \mathrm{v})$ agar containing $20 \%(\mathrm{w} / \mathrm{v}) \mathrm{NaCl}$ and covered with a cover slip. Gram stains were prepared as described by Dussault (1955). For scanning electron microscopy examination, $1 \mathrm{ml}$ samples were fixed overnight at $4{ }^{\circ} \mathrm{C}$ by adding formaldehyde to a final concentration of $7 \%$. Nine millilitres PBS (130 mM NaCl, 10 mM sodium phosphate, pH 7.2) was added to the samples, which were then filtered through $0 \cdot 2 \mu \mathrm{m}$ GTTP Millipore filters and washed with PBS. The filters were then serially dehydrated in $25,50,70$ and $100 \%$ ethanol solutions (three times for $10 \mathrm{~min}$ at each stage), critical-point dried, mounted on scanning electron microscope stubs, sputter-coated with gold and viewed on a JEOL JSM 840 scanning electron microscope.

Table 1. The Salinibacter strains isolated, with details of the source of isolation and further identifying information

\begin{tabular}{|c|c|c|c|c|c|}
\hline \multirow[t]{2}{*}{ Strain } & \multirow[t]{2}{*}{ Source and date of isolation } & \multirow[t]{2}{*}{$\mathbf{G}+\mathbf{C}$ content $(\mathrm{mol} \%)$} & \multirow[t]{2}{*}{ 16S rDNA accession no. } & \multicolumn{2}{|c|}{ DNA-DNA hybridization (\%) with: } \\
\hline & & & & $\mathbf{M} 1^{\mathrm{T}}$ & Pola-18 \\
\hline M1 & Mallorca, September 1999 & $66 \cdot 3$ & AF323499 & $87 \cdot 7$ & $71 \cdot 0$ \\
\hline M8 & Mallorca, September 1999 & $67 \cdot 0$ & AF323501 & $96 \cdot 6$ & $84 \cdot 4$ \\
\hline $\mathrm{M} 31^{\mathrm{T}}$ & Mallorca, September 1999 & $66 \cdot 5$ & AF323500 & 100 & $85 \cdot 0$ \\
\hline Pola-13 & Santa Pola, May 1999 & $66 \cdot 5$ & AF323503 & $99 \cdot 2$ & $78 \cdot 5$ \\
\hline Pola-18 & Santa Pola, May 1999 & $67 \cdot 7$ & AF323502 & $80 \cdot 5$ & 100 \\
\hline
\end{tabular}


Estimation of cell-associated potassium. Salinibacter ruber strains $\mathrm{M} 31^{\mathrm{T}}$ and Pola-18 were grown in medium B. Halobacterium salinarum $\mathrm{R} 1$ was grown in medium containing $\left(1^{-1}\right) 250 \mathrm{~g} \mathrm{NaCl}, 5 \mathrm{~g} \mathrm{KCl}, 5 \mathrm{~g} \mathrm{MgCl}_{2} \cdot 6 \mathrm{H}_{2} \mathrm{O}, 5 \mathrm{~g}$ $\mathrm{NH}_{4} \mathrm{Cl}$ and $10 \mathrm{~g}$ yeast extract, $\mathrm{pH} 7 \cdot 0$. Cells from the midexponential growth phase were collected by centrifugation $(1 \mathrm{~min}, 10000 \mathrm{~g})$ in $1.5 \mathrm{ml}$ plastic centrifuge tubes. Cell pellets, containing between 0.23 and $0.68 \mathrm{mg}$ protein, were washed once with a solution of $250 \mathrm{~g} \mathrm{NaCl} l^{-1}, 20 \mathrm{~g}$ $\mathrm{MgCl}_{2} \cdot 6 \mathrm{H}_{2} \mathrm{O}^{-1}, \mathrm{pH} 7 \cdot 0$. Pellets were then extracted with $0.2 \mathrm{ml} 10 \%$ perchloric acid for $2 \mathrm{~h}$ and extracts were diluted with distilled water to obtain $\mathrm{K}^{+}$concentrations between $0 \cdot 2$ and $0.5 \mathrm{mM}$. $\mathrm{K}^{+}$concentrations were determined by flame photometry. Cellular protein was determined in identically prepared cell pellets using the Lowry method (Lowry et al., 1951). All assays were performed with three or four replicates.

Biochemical tests. Most tests were performed as outlined by Holding \& Collee (1971), in most cases using medium A. Appropriate positive and negative controls were included in all experiments. Nitrate reduction was tested in liquid media supplemented with 5 or $10 \mathrm{~g} \mathrm{NaNO}_{3} 1^{-1}$. The formation of nitrite was monitored colorimetrically and formation of gaseous products from nitrate was detected by the presence of gas bubbles in Durham tubes. Hydrolysis of starch was examined on agar plates supplemented with $2.5 \mathrm{~g}$ soluble starch $1^{-1}$. Starch hydrolysis was detected by flooding the plates with iodine solution. Gelatin hydrolysis was determined by growing colonies on agar plates amended with $0.4 \%$ gelatin and flooding the plates with a solution of $15 \%$ (w/v) $\mathrm{HgCl}_{2}$ in $20 \%(\mathrm{w} / \mathrm{v}) \mathrm{HCl}$ after growth was obtained (Gutiérrez \& González, 1972). Hydrolysis of Tweens 20 and 80 was tested as outlined by Gutiérrez \& González (1972); Tween was added at a concentration of $1 \mathrm{ml} \mathrm{l}^{-1}$ to the autoclaved medium, in the case of medium A supplemented with $0 \cdot 2 \mathrm{~g} \mathrm{CaCl}_{2} \cdot 2 \mathrm{H}_{2} \mathrm{O} \mathrm{l}^{-1}$. Indole production was detected with Kovacs' reagent after having grown the cells in medium supplemented with $0 \cdot 1 \mathrm{~g}$ L-tryptophan $1^{-1}$.

To test for acid production from sugars, media were supplemented with 5 or $10 \mathrm{~g}$ of the sugars tested $\mathrm{l}^{-1}$ and the $\mathrm{pH}$ of the cultures was measured periodically with a $\mathrm{pH}$ electrode. When medium A was used in these experiments, glucose was omitted.

The presence of catalase was tested by adding a $1 \%(\mathrm{v} / \mathrm{v})$ $\mathrm{H}_{2} \mathrm{O}_{2}$ solution to colonies on plates. The presence of oxidase was determined with tetramethyl $p$-phenylenediamine hydrochloride (Holding \& Collee, 1971) or with Oxoid BR64A indicator sticks.

Sensitivity to antibiotics was tested in $30-\mathrm{ml}$ liquid cultures or in $2.5 \mathrm{ml}$ volumes in 125 -ml-well microtitre plates. The following antibiotics and antibacterial compounds were used, each at a concentration of $50 \mu \mathrm{g} \mathrm{ml}^{-1}$ : penicillin $\mathrm{G}$, ampicillin, streptomycin, novobiocin, bacitracin, chloramphenicol, kanamycin, tetracycline, ciprofloxacin, rifampicin, colistin, anisomycin and aphidicolin (the last added from a solution in DMSO).

Pigments were extracted from cell pellets with methanol/ acetone $(1: 1, \mathrm{v} / \mathrm{v})$ and absorption spectra were recorded against the solvent in a Hewlett Packard model 8452A diode array spectrophotometer.

DNA base composition and DNA-DNA hybridization. The $\mathrm{G}+\mathrm{C}$ content of the DNA was determined by HPLC and DNA-DNA hybridizations were performed by using a nonradioactive method as described by Ziemke et al. (1998).
Phylogenetic reconstruction. PCR-mediated amplification of the $16 \mathrm{~S}$ rDNA and purification of the PCR products were carried out as described previously (Benlloch et al., 1995, 1996). Template DNA was extracted from colonies of Salinibacter by using the Instagene matrix (Bio-Rad) according to the manufacturer's recommendations. PCR products were purified with the QIAquick PCR purification kit (Qiagen) and sequenced using the ABI Prism Terminator cycle sequencing ready reaction kit and ABI Prism 310 automated sequencer (Perkin Elmer) according to the manufacturer's instructions. For sequencing both strands of the complete $16 \mathrm{~S}$ rDNA, six primers were used: Ant 1 (Benlloch et al., 1995), S (Benlloch et al., 1995), EHB4F (5'ACACCCCTATGGGGCGTA-3'), EHB4R, (5'-TACGCCCCATAGGGGTGT-3'), EHB 9F (5'-TACCTAGGCTCGAACGCT-3') and EHB (5'-AGCCTTGCTCGGTAGGTA-3'). Primers with the prefix EHB, specific for 'Candidatus Salinibacter' sequences, were designed by comparing the EHB clones obtained from direct amplification of bacterial 16S rDNA from water from different solar salterns (Antón et al., 2000). New sequences were added to an alignment of about 18000 homologous bacterial 16S rRNA primary structures (Maidak et al., 2000; http// www.mikro.biologie.tu-muenchen.de) by using the aligning tool of the ARB program package (Ludwig \& Strunk, 1998). Distance-matrix, maximum-parsimony and maximum-likelihood methods were applied as implemented in the ARB software. Phylogenetic trees were reconstructed by using subsets of data that included complete or almost complete sequences of representative members of the Bacteria. Topologies were evaluated by using the different approaches to elaborate a consensus tree (Ludwig et al., 1998).

\section{RESULTS AND DISCUSSION}

\section{Enrichment and isolation}

In the course of this study, we have isolated five strains of halophilic red bacteria (Table 1), all very similar in their phenotypic properties and 16S rRNA gene sequences. They were selected from colonies that developed on agar plates inoculated with environmental samples on the basis of FISH with a specific probe (Antón et al., 2000) or on the basis of the presence of bacterial rather than archaeal polar lipids. For the Mallorca sample, 70 colonies grown on solid

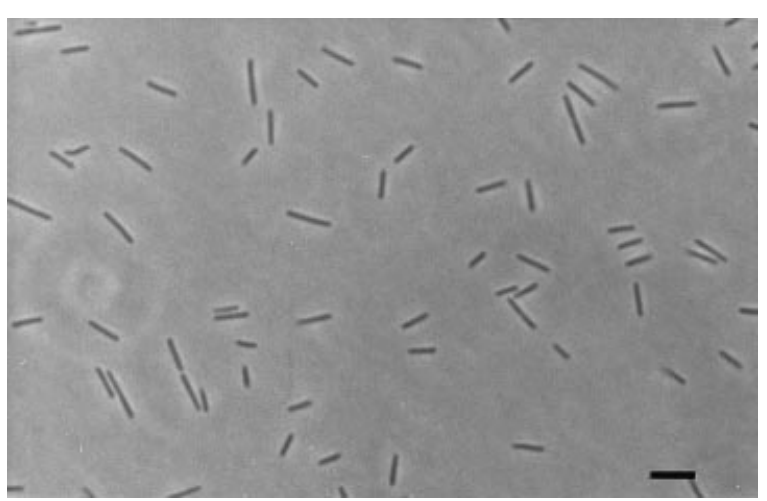

Fig. 1. Phase-contrast micrograph of Salinibacter ruber strain M31 $1^{\top}$. Bar, $5 \mu \mathrm{m}$. 


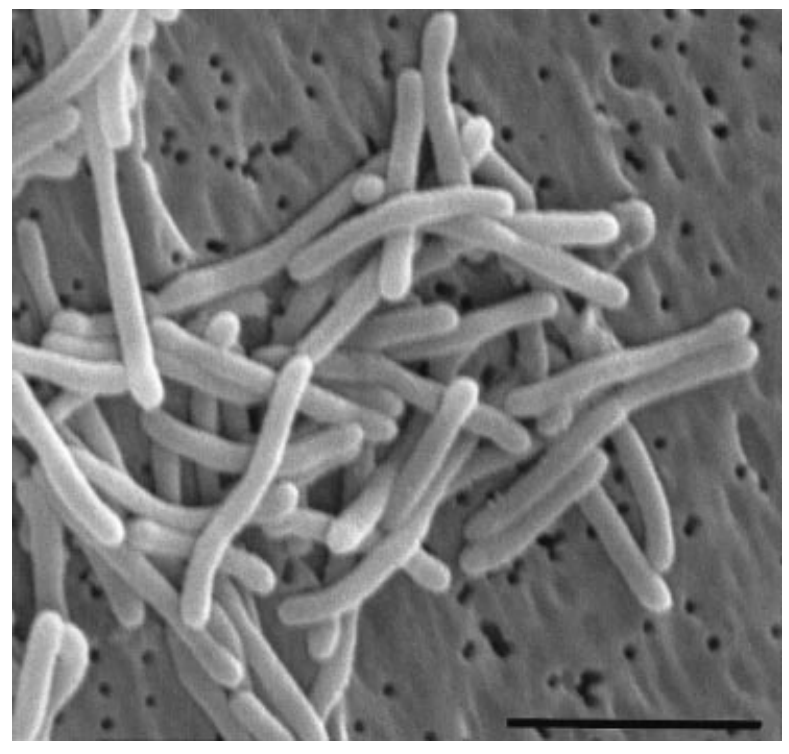

Fig. 2. Scanning electron micrograph of Salinibacter ruber strain $\mathrm{M} 31^{\top}$. Bar, $2 \cdot 5 \mu \mathrm{m}$.

medium were analysed and 23 gave positive FISH signals with the specific probe.

\section{Morphology, fine structure and pigmentation}

The bacteria were motile, straight or slightly curved rods, measuring 2-6×0.4 $\mu \mathrm{m}$ (Figs 1 and 2). Flagella were observed under the electron microscope after negative staining with phosphotungstic acid (data not shown), but no definitive information could be obtained on the number or localization of these flagella. After fixation with acetic acid (Dussault, 1955), the cells stained Gram-negative. Colonies on agar were red, about $1 \mathrm{~mm}$ in diameter, circular and convex with an entire margin. Pigment extracts in methanol/ acetone $(1: 1, \mathrm{v} / \mathrm{v})$ showed an absorption maximum at $478 \mathrm{~nm}$ and a shoulder at 506-510 nm. Similar spectral data were reported for the (yet to be chemically characterized) pigment of Rhodothermus marinus (Alfredsson et al., 1988). It remains to be determined whether this pigment is a carotenoid, possibly a flexirubin-like pigment common in the Cytophagales (Reichenbach, 1992), or may belong to a novel class of bacterial pigments.

It is noteworthy that bright-red pigmentation is common in micro-organisms inhabiting salt lakes and saltern ponds. Members of the Halobacteriaceae possess C-50 carotenoids of the bacterioruberin group. The role of this pigmentation in protecting against the harmful intensities of sunlight to which the cells are exposed in their natural environment was shown many years ago (Dundas \& Larsen, 1962). Most Dunaliella sp. alga cells found in salterns are similarly pigmented red due to a high content of $\beta$-carotene. The nature of the red pigment of the novel bacterium is yet to be determined. The red colour of most members of the
Halobacteriaceae has been used in the past as an easily recognizable character to discriminate between archaeal and bacterial members of the prokaryote community (Rodríguez-Valera et al., 1981). It is now becoming increasingly clear that colony colour itself is not a reliable trait to judge the phylogenetic affiliation of halophilic prokaryotes. Not only have colourless members of the Halobacteriaceae been isolated (e.g. Natrialba asiatica; Kamekura \& Dyall-Smith, 1995), but the presently described extremely halophilic member of the Bacteria produces colonies as brightly red as those of the typical red halophilic members of the Archaea.

\section{Growth and physiology}

The Salinibacter strains were extremely halophilic. They grew optimally at $20-30 \%$ total salts. The strains isolated from Mallorca did not grow at $15 \% \mathrm{SW}$ while the Santa Pola strains were somewhat less halophilic, since they grew at this salt concentration. All the strains could grow in solutions saturated with $\mathrm{NaCl}$. Near-optimal growth rates were obtained over the whole range of $\mathrm{Mg}^{2+}$ concentrations from below $0 \cdot 1$ to $0.6 \mathrm{M}$ for the Santa Pola strains, while strains isolated from Mallorca needed $0 \cdot 2 \mathrm{M}$ to grow optimally and did not grow at $0.05 \mathrm{M}$. High salt concentrations were not required for the maintenance of cell shape and cells did not lyse when suspended in distilled water. The optimal $\mathrm{pH}$ range for growth was $6 \cdot 5-8 \cdot 0$. The optimum temperature for growth was $32-47^{\circ} \mathrm{C}$. At $27^{\circ} \mathrm{C}$, growth was very slow, and no growth was observed at temperatures above $52^{\circ} \mathrm{C}$. Doubling times for the five strains in medium $\mathrm{B}$ incubated at $37^{\circ} \mathrm{C}$ ranged from 14 to $18 \mathrm{~h}$, according to data obtained from three independent experiments for each strain.

The Salinibacter strains were chemo-organotrophic and strictly aerobic. Oxidase and catalase reactions were positive. Nitrate was not reduced to nitrite or to gaseous products. High nutrient levels did not increase growth rates; in fact, very long lag times (up to more than $10 \mathrm{~d}$ ) were observed when the yeast extract concentration of medium B (see above) was increased to 5 or $10 \mathrm{~g} \mathrm{l}^{-1}$. Amino acids appeared to be the preferred nutrients for growth. Our attempts to design a defined medium were unsuccessful. Simple sugars and organic acids (acetate, succinate) did not support growth as sole carbon and energy sources. Addition of sugars and related compounds (glucose, glycerol, sucrose, ribose, fructose, xylose, lactose, mannitol, galactose, sorbitol, maltose) at concentrations of $5 \mathrm{~g} \mathrm{l}^{-1}$ to medium A did not stimulate growth greatly and did not result in acid production. All isolates hydrolysed gelatin. Starch was hydrolysed by most strains. Tween 80 was not hydrolysed, but a very weak hydrolysing activity towards Tween 20 was sometimes observed. No indole was produced from L-tryptophan.

The isolates proved sensitive to penicillin $\mathrm{G}$, ampicillin, chloramphenicol, streptomycin, novobiocin, rifampicin and ciprofloxacin. No inhibition by kanamycin, 


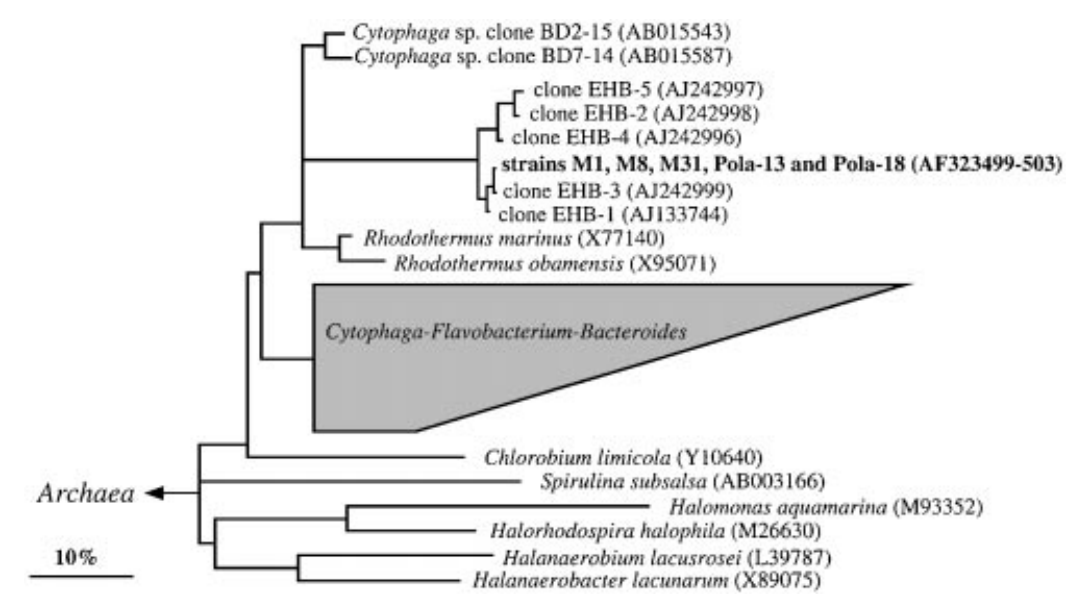

Fig. 3. Phylogenetic reconstruction based on 165 rDNA sequences from strains and clones affiliated to Salinibacter. The tree is based on the results of a parsimony analysis including only complete or almost-complete $16 \mathrm{~S}$ rDNA sequences of all sequences available of the phylum CytophagaFlavobacterium-Bacteroides (over 400) and representatives of the domain Bacteria (Maidak et al., 2000). The topology of the tree was corrected according to the results of distance-matrix, maximum-parsimony and maximum-likelihood analyses of various datasets as recommended by Ludwig et al. (1998). Multifurcations indicate where a topology could not be resolved unambiguously. Bar, $10 \%$ estimated sequence divergence. Accession numbers of individual sequences are shown on the tree. bacitracin, tetracycline, colistin, anisomycin or aphidicolin was observed.

Cells of Salinibacter contained extremely high concentrations of $\mathrm{K}^{+}$ions in their cytoplasm. In strain $\mathrm{M} 31^{\mathrm{T}}$, the level of $\mathrm{K}^{+}$was $11 \cdot 4 \pm 1 \cdot 1 \mu \mathrm{mol} \mathrm{K}{ }^{+}(\mathrm{mg} \text { protein })^{-1}$ ( $n=6$, derived from two independent experiments). In strain Pola-18, it was $15 \cdot 2 \pm 0 \cdot 6 \mu \mathrm{mol} \mathrm{K}^{+}$(mg protein $)^{-1}$ $(n=3)$. These values are in the same range as those detected in Halobacterium salinarum R1 $\left[12 \cdot 0 \pm 0 \cdot 7 \mu \mathrm{mol} \mathrm{K}^{+}(\mathrm{mg} \text { protein })^{-1}(n=7)\right.$, based on two independent experiments], an organism that uses $\mathrm{KCl}$ osmotically to balance the high $\mathrm{NaCl}$ concentration in its surrounding medium. It is thus suggested that Salinibacter uses a similar strategy of osmotic adaptation.

\section{Phylogenetic reconstruction and genomic characteristics}

Comparative analysis of the 16S rDNA sequences of the Salinibacter isolates resulted in a reconstructed phylogeny very similar to that observed previously when using 16S rDNA clones retrieved directly from the environment (Fig. 3). All sequences were affiliated with the two Salinibacter branches represented by EHB-1 and EHB-2 (Antón et al., 2000). All the strains analysed in this work had 16S rDNA sequences that were nearly identical (lowest similarity of $99.6 \%$ ) to sequence EHB-3, corresponding to a $16 \mathrm{~S}$ rDNA clone retrieved from a solar saltern in Ibiza. Together with this EHB-3 sequence, these strains clustered with sequence EHB-1, which was shown by FISH (Antón et al., 2000) to be the most abundant bacterial phylotype in crystallizer solar salterns in Santa Pola (Alicante, Spain). The strains showed sequence similarity values that ranged from 100 to $99 \cdot 7 \%$. Pola-13 and Pola-18 shared identical sequences.

The closest cultivated relative of our isolates is Rhodothermus marinus, a species of slightly halophilic (optimum $0 \cdot 5-2 \% \mathrm{NaCl}$ ), thermophilic (optimum
$65-70{ }^{\circ} \mathrm{C}$, maximum around $77^{\circ} \mathrm{C}$ ) bacteria isolated from marine hot springs (Alfredsson et al., 1988; Sako et al., 1996; Silva et al., 2000). The 16S rRNA sequence similarity between Rhodothermus and our isolates (about $89 \%$ ) is low enough to warrant classification of a new genus and to formalize the description of Salinibacter gen. nov.

The five isolates formed a homogeneous genomic group and DNA-DNA similarities among the strains were above $71 \%$ (Table 1 ). The $\mathrm{G}+\mathrm{C}$ content of the strains ranged between 66.3 and $67.7 \mathrm{~mol} \%$ (Table 1 ). The pooled standard deviations of both experiments were $1.2 \%$ (similarity) and $1.8 \mathrm{~mol} \%(\mathrm{G}+\mathrm{C}$ content $)$.

\section{Conclusion}

We have been successful in isolating five strains that correspond to a previously uncultured bacterial community that has been shown by molecular techniques to be abundant in saltern crystallizer ponds. The $16 \mathrm{~S}$ rRNA gene sequences of the isolates obtained were nearly identical to sequences recovered earlier from the saltern biomass. The rod-shaped morphology of the isolates was also very similar to that observed in the natural samples by using specific fluorescent oligonucleotides (Antón et al., 2000).

When examining their physiology, there is a surprising similarity between the newly isolated extremely halophilic bacterium and the archaea of the family Halobacteriaceae. Both groups are aerobic heterotrophs, many members of the Halobacteriaceae also have complex growth requirements and both maintain high intracellular $\mathrm{K}^{+}$concentrations. The isolates described here are among the most halophilic organisms known within the domain Bacteria; they require high salt concentrations, with optimum growth in the range $15-25 \%$ total salts. The five isolates exhibit a brightred pigmentation that is also common in halophilic archaea and even the $\mathrm{G}+\mathrm{C}$ content of their DNA is similar. 
The relatively slow growth rate of Salinibacter together with the remarkable similarity of their colonies to those produced by halophilic archaea explains why these organisms have previously escaped isolation. It is even probable that bacteria of the type described here have been isolated many times in the past but, because of the similarity of their colony morphology, they have mistakenly been considered as members of the Archaea.

The isolation of organisms harbouring 16S rRNA sequences and morphology nearly identical to those of 'Candidatus Salinibacter' allows a formal description of the genus Salinibacter gen. nov. The five isolates studied are sufficiently similar to be classified in a single species and we propose the name Salinibacter ruber sp. nov. as the type species of the novel genus. The type strain is strain M $31^{\mathrm{T}}$ (=DSM $13855^{\mathrm{T}}=$ CECT $5946^{\mathrm{T}}$ ), isolated from Mallorca.

\section{Description of Salinibacter gen. nov.}

Salinibacter (Sa.li.ni.bac'ter. L. fem. pl. n. salinae salterns, salt-works; N.L. masc. n. bacter masc. equivalent of the Gr. neut. n. bakterion a rod; N.L. masc. n. Salinibacter a rod from salt-works).

Rod-shaped or curved bacteria, phylogenetically loosely affiliated with the phylum CytophagaFlavobacterium-Bacteroides. Gram-negative. Aerobic, heterotrophic. Oxidase- and catalase-positive. Ex-

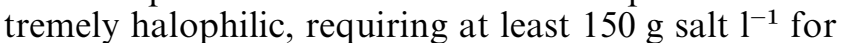
growth. Habitat: salt lakes and saltern ponds. The $\mathrm{G}+\mathrm{C}$ content of the type species is $66.5 \mathrm{~mol} \%$. The type species is Salinibacter ruber.

\section{Description of Salinibacter ruber sp. nov.}

Salinibacter ruber (ru'ber. L. adj. ruber red).

Cells are motile, straight or slightly curved rods, measuring 2-6 $60.4 \mu \mathrm{m}$. Colonies on agar are red, about $1 \mathrm{~mm}$ in diameter, circular and convex with an entire margin. Pigment extracts in methanol/acetone $(1: 1, \mathrm{v} / \mathrm{v})$ show an absorption maximum at $478 \mathrm{~nm}$ and a shoulder at 506-510 nm. Extremely halophilic, growing optimally at total salt concentrations of $150-300 \mathrm{~g} \mathrm{l}^{-1}$ and requiring at least $150 \mathrm{~g}$ salt $~^{-1}$ for growth. The optimal $\mathrm{pH}$ range for growth is $6 \cdot 5-8 \cdot 0$ and no growth is observed below pH 6.0 or above $\mathrm{pH} 8 \cdot 5$. Temperature optimum $37-47^{\circ} \mathrm{C}$. No growth above $52^{\circ} \mathrm{C}$. Nitrate is not reduced. No acid produced from sugars. Starch and gelatin are hydrolysed. Tween 80 is not hydrolysed and Tween 20 is hydrolysed weakly or not at all. No indole is produced from Ltryptophan. Sensitive to penicillin G, ampicillin, chloramphenicol, streptomycin, novobiocin, rifampicin and ciprofloxacin. Insensitive to streptomycin, kanamycin, bacitracin, tetracycline, colistin, anisomycin and aphidicolin. The $\mathrm{G}+\mathrm{C}$ content of the DNA is $66.5 \mathrm{~mol} \%$ (HPLC).
The type strain is strain $\mathrm{M} 31^{\mathrm{T}}$ (= DSM $13855^{\mathrm{T}}=$ CECT $5946^{\mathrm{T}}$ ), isolated from a saltern crystallizer pond in Mallorca, Balearic Islands, Spain.

\section{ACKNOWLEDGEMENTS}

We are grateful to Mr Miguel Cuervo for allowing access to the Santa Pola salterns and to Salinas de Levante S. A. for providing crystallizer samples. A. O. thanks Nona Dinevich for her help with the phenotypic characterization. J.A. thanks Arantxa Peña, Fernando Santos, Marina Torreblanca and Andrés Amorós for technical assistance. This study was supported by a European Commission grant MAS3-CT-97-0154, UMH.DCET.DM.B, MIDAS project. Further support was obtained from the Israeli Ministry of Science and Technology (MOST) and the Spanish Ministry of Foreign Affairs - the General Directorate of Cultural and Scientific Relations (to A. O. and F. R. V.), the Israel Science Foundation, founded by the Israel Academy of Sciences and Humanities (to A.O.), the interchange program Acciones Integradas HA1999-0013 CICYT-DAAD (to R. R.M. and R.A.) and the Spanish Ministry of Science and Technology grants BOS2000-1123C02-01 and BOS2000-1123C02-02 (to R.R.M. and J.A.).

\section{REFERENCES}

Alfredsson, G. A., Kristjansson, J. K., Hjörleifsdottir, S. \& Stetter, K. O. (1988). Rhodothermus marinus, gen. nov., sp. nov., a thermophilic, halophilic bacterium from submarine hot springs in Iceland. J Gen Microbiol 134, 299-306.

Antón, J., Rosselló-Mora, R., Rodríguez-Valera, F. \& Amann, R. (2000). Extremely halophilic bacteria in crystallizer ponds from solar salterns. Appl Environ Microbiol 66, 3052-3057.

Benlloch, S., Martínez-Murcia, A. J. \& Rodríguez-Valera, F. (1995). Sequencing of bacterial and archaeal 16S rRNA genes directly amplified from a hypersaline environment. Syst Appl Microbiol 18, 574-581.

Benlloch, S., Acinas, S. G., Martínez-Murcia, A. J. \& RodríguezValera, F. (1996). Description of prokaryotic biodiversity along the salinity gradient of a multipond solar saltern by direct PCR amplification of 16S rDNA. Hydrobiologia 329, 19-31.

Dundas, I. D. \& Larsen, H. (1962). The physiological role of the carotenoid pigments of Halobacterium salinarium. Arch Mikrobiol 44, 233-239.

Dussault, H.P. (1955). An improved technique for staining red halophilic bacteria. J Bacteriol 70, 484-485.

Gutiérrez, C. \& González, C. (1972). Method for simultaneous detection of proteinase and esterase activities in extremely halophilic bacteria. Appl Microbiol 24, 516-517.

Holding, A. J. \& Collee, J. G. (1971). Routine biochemical tests. Methods Microbiol 6A, 1-32.

Kamekura, M. \& Dyall-Smith, M. L. (1995). Taxonomy of the family Halobacteriaceae and the description of two new genera Halorubrobacterium and Natrialba. J Gen Appl Microbiol 41, 333-350.

Lowry, O. H., Rosebrough, N. J., Farr, A. L. \& Randall, R. J. (1951). Protein measurement with the Folin phenol reagent. J Biol Chem 193, 265-275.

Ludwig, W. \& Strunk, O. (1998). ARB: a software environment for sequence data. Department of Microbiology, Technische Universität München, Munich, Germany. http://www.mikro.biologie.tumuenchen.de

Ludwig, W., Strunk, O., Klugbauer, S., Klugbauer, N., Weizenegger, M., Neumaier, J., Bachleitner, M. \& Schleifer, K.-H. (1998). Bacterial phylogeny based on comparative sequence analysis. Electrophoresis 19, 554-568. 
Maidak, B. L., Cole, J. R., Lilburn, T. G. \& 9 other authors (2000). The RDP (Ribosomal Database Project) continues. Nucleic Acids Res 28, 173-174.

Oren, A. (1994). The ecology of the extremely halophilic archaea. FEMS Microbiol Rev 13, 415-440.

Reichenbach, H. (1992). The order Cytophagales. In The Prokaryotes: a Handbook on the Biology of Bacteria-Ecophysiology, Isolation, Identification, Applications, pp. 3631-3675. Edited by A. Balows, H. G Trüper, M. Dworkin, W. Harder \& K.-H. Schleifer. New York: Springer.

Rodríguez-Valera, F., Ruiz-Berraquero, F. \& Ramos-Cormenzana, A. (1980). Behaviour of mixed populations of halophilic bacteria in continuous cultures. Can J Microbiol 26, 1259-1263.

Rodríguez-Valera, F., Ruiz-Berraquero, F. \& Ramos-Cormenzana,
A. (1981). Characteristics of the heterotrophic bacterial populations in hypersaline environments of different salt concentrations. Microb Ecol 7, 235-243.

Sako, Y., Takai, K., Ishida, Y., Uchida, A. \& Katayama, Y. (1996). Rhodothermus obamensis sp. nov., a modern lineage of extremely thermophilic marine bacteria. Int J Syst Bacteriol 46, 1099-1104.

Silva, Z., Horta, C., da Costa, M. S., Chung, A. P. \& Rainey, F. A.

(2000). Polyphasic evidence for the reclassification of Rhodothermus obamensis Sako et al. 1996 as a member of the species Rhodothermus marinus Alfredsson et al. 1988. Int J Syst Evol Microbiol 50, $1457-1461$.

Ziemke, F., Höfle, M. G., Lalucat, J. \& Rosselló-Mora, R. (1998).

Reclassification of Shewanella putrefaciens Owen's genomic group II as Shewanella baltica sp. nov. Int J Syst Bacteriol 48, 179-186. 